\title{
Environmental Management Plan (EMP) for Melamchi Water Supply Project, Nepal
}

\author{
Khadka, R. B. ${ }^{1 *}$ and Khanal, A. B. ${ }^{2}$ \\ ${ }^{1}$ School of Environmental Management and sustainable Development, \\ Pokhara University, Nepal, \\ ${ }^{2}$ Melamchi water Supply Board, Baneswore, Kathmandu, Nepal
}

\begin{abstract}
Received 27 Jan. 2007;
Revised 26 July 2007;

Accepted 10 Aug 2007

ABSTRACT: More than 1.5 million people live in the Kathmandu valley. The valley is facing an extreme shortage of water supply. At the same time the demand is escalating rapidly. To address this issue of scarcity of water, the government of Nepal has proposed a project of inter- basin transfer of water from Melamchi River located $40 \mathrm{Km}$ north-east of the Kathmandu valley. The project will cover two districts and three municipalities and will potentially have significant impacts on the environment. In accordance with the Environmental Protection Regulation of Nepal (1997), the Melamchi Water Supply Project (MWSP) has undergone an EIA during the feasibility study stage of the proposed project. The recommendations contained in the EIA were integrated into the project design for implementation in 2006. This paper summarizes the background of MWSP, the environmental concerns described in the EIA and the status of Environmental Management Plan (EMP) developed to address environmental compliance and other issues involving participation and support of the local people. This paper also provides some lessons to learn on the modalities of addressing the demands and grievances of the local people concerning environmental management.
\end{abstract}

Key words: Environmental Impact Assessment, Environmental Management Plan, Impact Prediction, Mitigation measures, Monitoring and Public Participation

\section{INTRODUCTION}

Katmandu valley is the capital of Nepal. Over 15 million people inhabit the valley. The valley is facing acute shortage of drinking water supply. At present 140 Million Liters per day (MLD) of water is being supplied in the rainy season and 90 MLD during the dry season. The average demand of drinking water is 180 MLD.The Population of the valley is increasing at the rate of 3.3 percent. The demand for water supply is escalating. The Water Supply Corporation of Nepal has tapped all possible sources of water for Kathmandu (MWSDB, 2003).

The need for an additional source of water from outside the valley has been realized since 1970 (Bennie and Partners, 1988). Of the several options investigated, a snow-fed, perennial Melamchi River was deemed to be the most viable

\footnotetext{
*Corresponding author: Email-rbkhadka@wlink.com.np
}

source (Stanley and Associates, 990). The Government of Nepal completed its engineering design in 2000. The project consisted of five major components: access roads, water conveyance tunnel, water treatment plant, distribution system and waste water treatment plant. The fund required for implementation of the project was made available by different sources: Asian Development Bank (ADB) is the major contributor for the implementation of the project. An environmental study was carried out, which conducted comparatives analysis among potential sites of the out side sources. Melamchi Water Supply Project (MWSP) was found environmentally suitable (Stanley and Associate 1990). An EIA report prepared in 1999 included comprehensive baseline information (IUCN, 1999). A similar EIA report prepared in 2000 and has fulfilled the requirements of Environmental 
Protection Regulation of Nepal (1997), and the donors (Koei, 2000). A supplementary EIA report was also prepared (METCON Consultants, 2001). The MWSP covers a part of Indrawati and Bagmati watershed and includes areas of five districts. The key water diversion facilities are located within Sindhupalchowk and Kavrepalanchowk districts, whereas, water treatment plant, water distribution and the ancillary structures, will be located within Kathmandu valley (BPC Hydro consult, 1996). Four project objectives were identified for the project: (1) provide safe and clean drinking water to the people of the Kathmandu valley; (2) reduce pollution load of the rivers through waste water treatment; (3) improve River Ecology and Religious site, and (4) improve recharging of the ground water Fig. 1 shows the location of MWSP and the potential area to be impacted by the project. The MWSP is located within the middle and high mountains in the Melamchi and Kathmandu valley of Nepal. MWSP is an inter- basin water diversion project and involves two watersheds: Indrawati and Bagmati. The will divert 170 MLD of water from Melamchi River through $26.5 \mathrm{~km}$ tunnel. Basically, the Project consists of: Melamchi Diversion Scheme (MDS), Water Treatment Plant (WTP), Bulk Distribution System (BDS), Rehabilitation of Water Supply and Distribution (RWSD) and Restoration of Sewerage System (RSS). A $22 \mathrm{~km}$ long narrow muddy road to Melamchi Pool Bazaar will require expansion and upgrading. An $18 \mathrm{~km}$ long road is being constructed to the intake site. The existing road to Water Treatment Plant at Sundarijal also needs an extension and upgrading. Adit Access Roads (AARs) constitute Ambathan Adit (2 km) Gyalthum Adit (5 km) and Sindhu Adit (15.2 km) roads. Approximately $57,000 \mathrm{~m}^{3}$ of aggregates is estimated to be extracted. A total of $46,000 \mathrm{~m}^{3}$ of tunnel muck will be generated. Disposal sites for muck will be identified and will be located at each Adit point (NORPLAN, 1999).

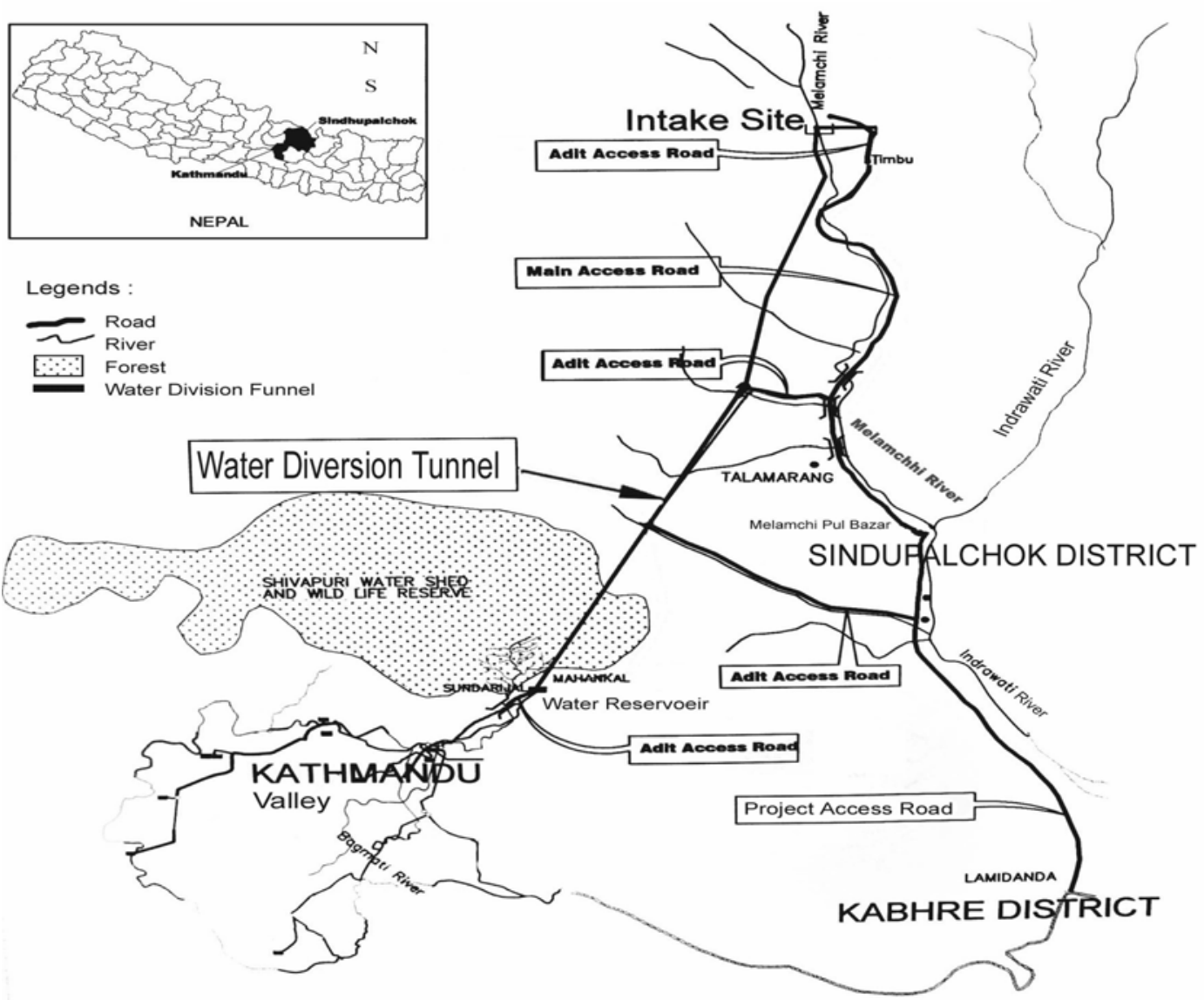

Fig.1. Location of melamchi wates supply project 


\section{MATERIALS \& METHODS}

About 900-2,500 individuals will be employed during the construction at MDS6. A total of 194.73 ha of land have been estimated to be acquired at the Melamchi valley, whereas a total of 115 ha of land are estimated to be required at the Kathmandu valley. A $40.5 \mathrm{~km}$ long electricity transmission line will be extended to the headwork and adit points. The estimated budget for the project is US\$ 464 million (Nippon Koei, 2000).

The upper and middle parts of Melamchi valley have temperate and sub-tropical climates, while the lower part is tropical. Heavy rainfall occurs during June, July and August. Agriculture, grazing and deforestation have accelerated erosion in the valley. Melamchi River originates at Jugal Himal at an elevation of 5,875 $\mathrm{m}$. The length of River is $41 \mathrm{~km}$ and the catchments area at the intake is $155 \mathrm{~km}^{2}$. The river flows southwards and widens towards the downstream. The mean annual flow is $9.7 \mathrm{~m}^{3} / \mathrm{s}$. The maximum flow is $289 \mathrm{~m}^{3} / \mathrm{s}$ in August. The tributaries contribute a flow of $1.01 \mathrm{~m}^{3} / \mathrm{s}$ during the dry period. Air quality is reasonably good, and the sound level generated by the flow of the river ranges from 40 to 60 decibel (IUCN, 1999).

Part of the project falls within tropical zone (below $1,000 \mathrm{~m}$ ), and is dominated by Shorea robusta forest. The sub-tropical zone $(1,000 \mathrm{~m}$ 2,000 m) is dominated by Schima- Castanopsis. Rhododendron and Pinus wallichiana are available above $2,000 \mathrm{~m}$. Langtang National Park (LNP) contains alpine flora and fauna. The intake site falls within the buffer zone. The LNP is a common habitat for 236 species of birds and 25 species of mammals. There are 45 species of fish in Melamchi River; five species of them are migratory, and seven species are vulnerable (IUCN, 1999).

Indrawati watershed straddles Sindhupalchowk and Kavarepalanchowk districts. The total population of these two districts is 585,354 . The average family size per household is 5.42 (1991, Central Bureau of Statistics; CBS). Tamangs, Brahmin, Chhetries, Newar and other minorities are resident here. Agriculture is the dominant occupation while the average land holding is 0.62 ha in Sindhupalchowk and 0.80 ha in Kavrepalanchowk. Maize, paddy, wheat and millet are the principal crops. MWSP activity includes within 17 VDCs. The total population of these VDCs is 68,882 (CBS, 1991).

Melamchi valley produces, 17,883 metric tons of paddies, while requirement of food grain is only 11,027 metric tons/yr. Off-farming activities include water mills, trading, and fishing and tourism. Helambu is a very well-known tourists' destination. The per capita income is Rs 6,571 (IUCN, 1999). Sixty percent of the households of the project area have access to safe drinking water, 25 percent have latrine and 60 percent have their own garbage pits (Koei, 2000) the literacy rate is 46 percent. Water mills, microhydro and irrigation projects are utilizing water from Melamchi River. The total water requirement in Melamchi valley is estimated to be $3.5 \mathrm{MLD}$ and for irrigation requirements is 2,140 L/sec. Several Ghats are being used to cremate dead bodies along the Melamchi River bank (IUCN, 1999).

The Katmandu valley is located within the sub-tropical zone. The average temperature is $24^{\circ} \mathrm{C}$ and the mean annual rainfall is $1,900 \mathrm{~mm}$. Bagmati River originates at the Shivapuri hills and drains $558 \mathrm{~km}^{2}$. The average annual maximum flow is $254.4 \mathrm{~m}^{3} / \mathrm{s}$ and the minimum flow is $0.13 \mathrm{~m}^{3} / \mathrm{s}$. The river water is extremely polluted and even toxic. The ambient air contains high amount of TSP, $\mathrm{PM}_{10}$, lead, $\mathrm{SO}_{\mathrm{x}}, \mathrm{NO}_{\mathrm{x}}$, and $\mathrm{CO}_{2}$, all exceeding the standard thresholds (IUCN, 1999).

The upper part of valley is occupied by Alnus nepalensis, Pinus roxburghii, Quercus semicarpifolia and Rhododendron. The lower and middle parts are occupied by Schima castanopsis, Pinus roxburghii, and Quercus incana. There are 1,312 species of plants in record. Shivapuri Wildlife Reserve (SWR) is located near to the project site and contains 1,000 species of plants, 177 species of birds, and some species of mammals (Chaudhary, 1998).

The valley consists of one Metropolitan and two Sub-Metropolitan Cities. The population of the valley is estimated to be 1,551,621 (CBS, 2000). Newars, Chetries, Brahmins, Tamang and other caste groups are residents in the valley. Altogether, 41 VDCs and Municipalities are likely 
to be affected by the Project. People of the valley are employed in manufacturing, trade and commerce, agriculture, transport and almost every occupation. The range of household income varies from Rs. 3, 999 to 15,999 per month. About 70 percent of the people are literate (IUCN, 1999). About 54 percent of the households in the valley have access to drinking water supply, 70 percent have access to sanitation facilities and 52 percent have connection to sewerage system (Koei, 2000). Hindu temples and cremation sites also require considerable amount of water. Because of pollution, the water in the Bagmati River is extremely unsuitable for aquatic animals and plants and other uses. There are several waste treatment plants installed at various locations. However, at present most of them are not functioning.

\section{Environmental Impacts}

The project area is classified as i) Direct Impact Zone (DIZ) within the periphery of $500 \mathrm{~m}$ from the main project site and ii) the Indirect Impact Zone (IIZ) beyond $500 \mathrm{~m}$ from the project sites (IUCN,1999). A total of 17 VDCs are classified as DIZ. The following impacts are predicted to occur during the construction and operation phases of the project (Koei, 2000).

\section{Soil erosion/sedimentation/ slope instability}

Impacts likely to occur from the construction and operation of the main and adit access roads, transmission line, quarry and borrow pits may include the impacts such as, erosion and landslides, siltation and sedimentation, spoils generation and their disposals, degradation of agriculture land, and disruption of irrigation canal and other infrastructures.

\section{River morphology, hydrology and water pollution}

During construction and operation of access roads, there will be no major impacts in the river hydrology. The possible causes of water pollution are: dumping of spoil materials into the river, excavation of the boulders from the river may change river course, direct disposal of liquid wastes and leakage of oil and lubricants, a flow of $1.97 \mathrm{~m} / \mathrm{s}$ to be diverted into tunnel is likely to affect the downstream river hydrology particularly during the month of January to April.

\section{Tunnel construction and tunnel muck disposal}

In the process of tunnel construction, the impacts likely to occur are: instability of the slopes, vibration, damages to the houses, disruption of water flow along tunnel route, and land slides, and production of $459,200 \mathrm{~m}^{3}$ of tunnel muck which may need 1. 95 ha of land for disposal, river pollution and turbidity due to disposal of oil and slurry disposal.

Water Treatment Plants (WTP), Bulk Distribution System (BDS), and Waste Water Treatment Plants(WWTP) in the Kathmandu Valley

During the construction and operation of WTP, BDS, and WWTP the following impacts are anticipated; haphazard disposal of spoil materials may create erosion problems, the existing drainage lines will be disturbed, changes will occur in the existing land use practices, BDS construction may require, laying of $58 \mathrm{~km}$ long pipes, into 3 to $5 \mathrm{~m}$ deep and will generate $450,000 \mathrm{~m}^{3}$.of spoil materials. Some part of it may be used filling the trench back, however, the major parts needs proper disposal, distribution pipe will cross 36 rivers and creeks and create erosion and other problems, and disruption of the taps, wells, spouts and other sources of water may create some problems to the local people. However the increased flow in Bagmati River will have some beneficial impacts: 65 percent of water supplied will return to Bagmati River after treatment and pollution load will be reduced.

\section{Waste Production: MDS, WTP, BDS, and WWTP}

In the process of construction and operation of MDS, WTP, BDS, and WWTP some amount of wastes will be generated. Construction of 42.2 $\mathrm{km}$ of road and 26.5 tunnels will generate 980,625 $\mathrm{m}^{3}$ and $460,000 \mathrm{~m}^{3}$ of wastes and tunnel muck respectively. WTP and WWTP will generate $15330 \mathrm{~m}^{3}$ and $756,000 \mathrm{~m}^{3}$ of sludge respectively every year. In addition to these, 2 to 3.5 tons of human wastes will be produced by the construction workers every day. Packing materials, explosive wastes, steel wire, and metallic plates would also constitute a substantial amount to waste matters. 


\section{RESULTS \& DISCUSSION}

\section{Impact on Air quality and Noise level}

Excavation of construction materials, aggregate crushing, drilling, blasting, quarrying and plying of vehicles may produce hydrocarbons, $\mathrm{CO}$, $\mathrm{CO}_{2}, \mathrm{SO}_{2}, \mathrm{NO}_{\mathrm{X}}, \mathrm{TSP}, \mathrm{H}_{2} \mathrm{~S}$ and $\mathrm{CH}_{4}$ etc. Plying of trucks in non-metallic roads may produce huge amount of dust. These may also increase the noise level above $90 \mathrm{dBA}$. Intense vibration during blasting may trigger the cracking of the houses and collapsing of structures within $3 \mathrm{~km}$ from blasting point. The sound level may rise to 130 $\mathrm{dBA}$ during the period of blasting.

\section{Ecological Impacts}

In total, 2815 trees will have to be removed particularly from the MDS, and WTP sites. Habitat destruction may take place along the river course. As a consequence, some mammals and birds will be affected. Illegal poaching may take place by workers and the migratory routes of the mammals will be blocked. The construction activities can destroy the breeding sites of the fish and the intake will block the migratory route of fish. Construction workers may kill the fish. Some fish may get trapped into the intake structure. Reduced downstream flow of the river will affect the production of fish food, whereas increased water flow in Bagmati River will improve the fish habitat and ecology.

\section{Socio-Economic and Cultural Impacts}

Loss of land and other properties: In the process of construction of access road at MDS, 194.73 ha of land will be required by the project. In total 2,122 households will be affected and 108 structures (house, water mills and cowsheds) will be required to be demolished. In the construction of Water Treatment Plants, 12 ha of agriculture land and 67 households will be affected. In total, 103 ha of land and 4,239 households will be affected from construction activities at the Melamchi Valley.

\section{Irrigation, Water Mill, Fishing and Recreation at Melamchi Valley}

A flow of $0.2 \mathrm{~m}^{3} / \mathrm{s}$ from Melamchi River is being used for irrigation of the farming land. Reduced water flow downstream might create some social and economical problems after the diversion. Several water mills will be affected. Nearly 200 people of 734 families are engaged in fishing activities will be affected (NORPLAN, 2000A).

\section{Crime level, Local service, and Traffic Congestion}

Alcohol abuse, gambling, prostitution and other social disharmony are likely to arise in the construction site. Outside workers will come to the project site with their immediate family members. This will create unwanted congestion and exert pressure on the limited resources. Nearly 90 heavy vehicles will be plying daily for the transport of construction materials possibly creating traffic congestion.

\section{Employment, Local and National Economy}

Nearly 1,020 skilled and semiskilled workers will be working at MDS and 320 workers jobs will be available every day during the construction of Water Treatment Plant. Approximately 1,100 workers will be employed every day for the construction of BDS and WWTP. About 60 percent of the workers required for the project are available locally. According to EIA report at least 30 percent of the workers should be local and 5 percent should be women.

\section{Project cost and Benefits}

The total project cost was estimated to be US\$ 436 million. The analysis indicated that the Internal Rate of Return (IRR) is 13.5 percent. The total cost for the implementation of Environmental Management Plan (EMP) is estimated to be US\$ 26 million (5.9\% of the total project cost) which includes the cost for implementation of mitigation measures, compliance monitoring, and implementation of RAP and SUP activities (Koei, 2000). The project will also contribute to the national economy. Approximately 30 percent of total budget will remain within the country. The project may create new job opportunity; establish the linkage with international institutions. Nepali engineers will have an opportunity to learn to apply new technologies. Nepali entrepreneurs will have an opportunity to establish industries to produce huge quantity of construction materials required by the project. 


\section{Mitigating Possible Environmental Impacts Physical and Biological Environment}

The following mitigation measures have been proposed to be implemented in order to minimize the anticipated impacts in Environmental aspects. Mitigation measures recommended to ameliorate the effects of soil erosion, sedimentation and slope stability and water pollution are adoption of cut and fill principles, construction of side drains and culverts, minimization of the removal of vegetation, storing of scraped top soil, prohibition of side-casting, implementation of bio-engineering to control erosion, prohibition of erection of electric pole in steep slope, prohibition of excavation from the wet channel of the river, treating of the liquid waste from construction site and camps, and storage sites prior to its release to the river, release a flow of $0.4 \mathrm{~m} 3 / \mathrm{s}$ down stream, and a provision for toilets and garbage pit to dispose the domestic waste.

To minimize the effects of tunneling and other construction activities, the measures such as controlled blasting, concrete lining of tunnel surface to prevent the water leakage, use of designated land for muck disposal, and compaction, development of drainage networks and top soil application over the surface of muck disposal area, avoidance of construction during monsoon, prohibition of disposal at the drainage line, minimization of the use of heavy vehicles, and use of existing sites for mining of aggregates have been recommended in EIA. The sludge from the Waste Treatment Plant may contain aluminum which is toxic to the plant. Therefore its disposal should be carried out through land filling process. Regular sprinkling of water of the dusty roads, compaction of the dumping sites, gravelling of earthen roads, limiting the speed of the vehicle, complying with mass emission standards, installation of stacks in the crushing plants are some of the measures recommended to reduce air pollution.

For minimization of the ecological impacts, the trees should be cut only within the pegged area. The harvesting of local trees should be prohibited for the use as firewood, timber and other purposes. Three trees should be planted for every tree removed as compensatory plantation measures. Trees cut from private owners and community forests should be appropriately compensated. No workers should be allowed to hunt wild animals in the project area.

To maintain aquatic life in downstream, a flow of $0.4 \mathrm{~m} 3 / \mathrm{s}$ should be released. A trout nursery should be established at Timbu to compensate the loss of fish population. A fish screening device should be installed at the intake and workers should be instructed not to indulge themselves in fishing (IUCN, 1999).

\section{Socio-Economic and Cultural Environment}

EIA has recommended to adequately paying compensation of land and other properties to be occupied by the project. Compensation Fixing Committee, chaired by Chief District Officer (CDO) determines the prices of land and other properties at the current rate. Beside this, compensation and resettlement policy of the government may also be applicable to all decisions to be made during the project implementation. The EIA has also suggested development of Resettlement Action Plan (RAP) to address the direct adverse impacts and Social Uplift Program (SUP) to address indirect impacts which include rural electrification, health, and education etc, for the people of affected area (Nippon Koei, 2000).

The construction contractor has formulated strict regulation as a part of Environmental Mitigation Execution Plan (EMEP) which regulates the activities of workers. The contractor has to seek assistance from local police, if any crime occurs, and awareness program should be launched on the issues of health and diseases (IUCN, 1999).

In order to translate EIA prescriptions into actions, Environmental Management Plan (EMP) was developed and integrated into project design for implementation. The EMP document included: i) implementation of prescribed mitigation measures; ii) responsible agencies for implementation and review; iii) compliance monitoring; and iv) reporting of the findings of monitoring (EMP, 2000). Table 1 summarizes the comprehensive, systematic and tiered monitoring mechanism has been devised and implemented. 
Table 1. An Approach and modality of the implementation of Environmental Management Plan (EMP) for the MWSP

- Malamchi Water Supply Development Board (MWSDB) established to stay informed on the monitoring
outputs Through monthly progress report
Monthly progress reports on EMP implementation status submitted to concerned funding agencies and the
joint Review mission
Environmental, Resettlement and Social Development Division (ERSDD) headed by Senior Divisional
Engineer assigned to oversee the Environmental Monitoring activities undertaken by the EMP consultants.
The EMP programs are implemented on the direction and instruction of the ERSDD
Project Management consultant (PMC) routinely informed on the status of EMP implementation
At the level, EMP CONSULTANT CARRY out monitoring of the EMP components and parameters as
specified in the EIA (2000); analyze the frontline monitoring report submitted by the consulting engineer
and produce a second order monitoring report that is included in the monthly progress report
The consulting engineer prepares a monthly frontline EMP monitoring report and submits it to the MWSDB
Construction contractor is responsible to implement approved Environmental Mitigation Execution Plan;
contractors prepare a monthly progress report and submit it to the MWB through the consulting engineer.

Table 2. KEY Environmental Parameters monitored during the MWSP implementation

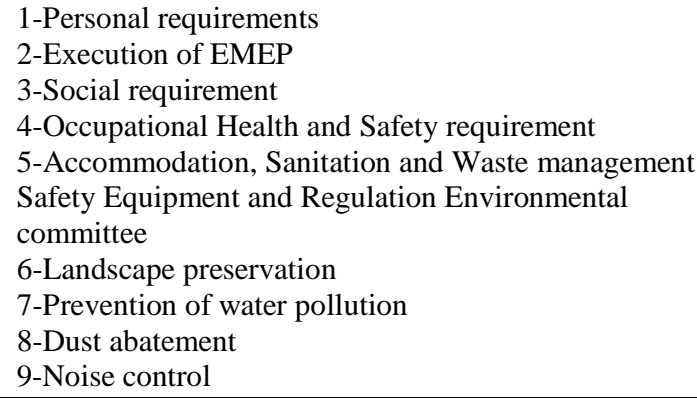

As per the contractual obligations of the consulting engineers and EMEP obligations of the contractors, the EMP compliance parameters have been monitored by the consulting engineers and the trend of meeting of compliance conditions have been analyzed for 2005 and 2006. From May to August 2005, the information was obtained from NORPLAN as a front line monitoring report. From October 2005 to December, 2005, the frontline monitoring reports of Environmental compliance was not submitted by consulting engineers. However, the EMP consultants carried out the compliance monitoring. Table 2 list the key parameters monitored by the consulting engineers during project construction.Analysis of monthly report of frontline monitoring indicated that EMP compliance was extremely low in the beginning (23\% in May 2005), however, it was improved considerably at the latter stage (77\% in August). After withdrawal of NORPLAN, as consulting engineer, there was vacant from September 2005 onwards. However, after the appointment of new consulting engineers at the site, the meeting of environmental compliance started to pick- up again and reached $80 \%$ in January and 90\% in February and in March, 2006. The status of meeting of environmental compliances remained pretty high during 2006 with some exception particularly during monsoon and afterwards. Cases of noncompliance were very few and the reasons for improving the compliance conditions are; the consultant engineers seem to be very serious on the compliance of environmental regulation; contractor appointed qualified environmental engineers; construction workers received training on EMP compliance and in the case of noncompliance, a provision for penalty was imposed.

\section{Impacts- Predicted and Perceived}

As the first part of the project, access roads construction is the main activity going on at present. The compliance monitoring of the access road construction, baseline monitoring on fish and fisheries, regular measurement of river flow and downstream water utilization, biodiversity monitoring, development of forest nursery and several other social and scientific works are being carried out as per EMP requirements. Some of the EMP parameters and impacts examined in the field have been compared with the impact predicted in EIA and status of EMP compliance has been estimated. The result of comparison is given in Table 3.

\section{Key Social Concerns}

Melamchi Water supply is one of the unique projects, where many grievances and demands of the local people are being submitted to MWSDB for actions. The project has allocated two types of environmental funds: i) mitigation of 
Table 3. Some of Predicted and Actual Impacts and Compliance Status

\begin{tabular}{|c|c|c|c|c|c|}
\hline $\begin{array}{l}\text { Component/ } \\
\text { Parameters }\end{array}$ & $\begin{array}{l}\text { Types of } \\
\text { Activities }\end{array}$ & $\begin{array}{l}\text { Impact } \\
\text { Predicted in } \\
\text { EIA }\end{array}$ & $\begin{array}{l}\text { Perceived } \\
\text { Impacts }\end{array}$ & Mitigation Measures & $\begin{array}{l}\text { Compliance } \\
\text { status (\%) }\end{array}$ \\
\hline $\begin{array}{l}\text { Physical: } \\
\text { 1) Slope }\end{array}$ & $\begin{array}{l}\text { Constructio } \\
\mathrm{n} \text { of Roads }\end{array}$ & $\begin{array}{l}55 \text { erosion prone } \\
\text { sites }\end{array}$ & $\begin{array}{l}42 \text { erosion } \\
\text { prone sites }\end{array}$ & $\begin{array}{l}\text { Slope stabilization and } \\
\text { Bioengineering }\end{array}$ & 80 \\
\hline $\begin{array}{l}\text { 2) Water } \\
\text { Quality }\end{array}$ & $\begin{array}{l}\text { Constructio } \\
\mathrm{n} \text { of Roads }\end{array}$ & $\begin{array}{l}\text { water quality is } \\
\text { expected to be } \\
\text { polluted }\end{array}$ & $\begin{array}{l}\text { water Quality } \\
\text { parameters are } \\
\text { within WHO } \\
\text { GV standards }\end{array}$ & $\begin{array}{l}\text { Spoils are properly } \\
\text { managed }\end{array}$ & 10 \\
\hline 3) Air quality & $\begin{array}{l}\text { Constructio } \\
\mathrm{n} \text { of Roads }\end{array}$ & $\begin{array}{l}\mathrm{PM}_{10} \text { and TSP are } \\
\text { expected to } \\
\text { increase }\end{array}$ & $\begin{array}{l}\text { TSP and } \mathrm{PM}_{10} \\
\text { have exceeded } \\
\text { the threshold }\end{array}$ & Water sprinkling & 50 \\
\hline 4) Noise level & $\begin{array}{l}\text { Constructio } \\
\mathrm{n} \text { of Roads }\end{array}$ & $\begin{array}{l}\text { expected to } \\
\text { increase more } \\
\text { than } 75 \text { dBA }\end{array}$ & $\begin{array}{l}\text { 65dBA during } \\
\text { construction }\end{array}$ & Blasting was not done & 90 \\
\hline $\begin{array}{l}\text { Biological: } \\
\text { 5) Fish species }\end{array}$ & $\begin{array}{l}\text { Constructio } \\
\mathrm{n} \text { of Roads }\end{array}$ & $\begin{array}{l}45 \text { species are } \\
\text { Available }\end{array}$ & $\begin{array}{l}63 \text { species are } \\
\text { found to exist }\end{array}$ & $\begin{array}{l}\text { Water diversion is still } \\
\text { to take place }\end{array}$ & - \\
\hline 6) Trees cut & $\begin{array}{l}\text { Constructio } \\
\mathrm{n} \text { of Roads }\end{array}$ & $\begin{array}{l}2815 \text { trees are } \\
\text { expected to be } \\
\text { cleared }\end{array}$ & $\begin{array}{l}\text { So far } 17347 \\
\text { trees have been } \\
\text { removed }\end{array}$ & $\begin{array}{l}\text { plantation is still to be } \\
\text { carried out }\end{array}$ & - \\
\hline $\begin{array}{l}\text { 7) Mammals } \\
\text { and Other } \\
\text { fauna } \\
\text { Socio-Economy: }\end{array}$ & $\begin{array}{l}\text { Constructio } \\
\mathrm{n} \text { of Roads }\end{array}$ & $\begin{array}{l}\text { Some impacts } \\
\text { have been } \\
\text { predicted }\end{array}$ & $\begin{array}{l}\text { No tangible } \\
\text { impacts have } \\
\text { been recorded }\end{array}$ & $\begin{array}{l}\text { Mitigation measures } \\
\text { implemented }\end{array}$ & - \\
\hline $\begin{array}{l}\text { 8) Land } \\
\text { Acquisition }\end{array}$ & $\begin{array}{l}\text { Constructio } \\
\mathrm{n} \text { of Roads }\end{array}$ & 194.75 ha & 120 ha & $\begin{array}{l}\text { Compensations were } \\
\text { paid }\end{array}$ & 90 \\
\hline $\begin{array}{l}\text { 9) Affected } \\
\text { households }\end{array}$ & $\begin{array}{l}\text { Constructio } \\
\mathrm{n} \text { of Roads }\end{array}$ & $\begin{array}{l}2122 \text { house-holds } \\
\text { are expected to be } \\
\text { affected }\end{array}$ & $\begin{array}{l}125 \text { households } \\
\text { are affected so } \\
\text { far }\end{array}$ & Compensations paid & 90 \\
\hline $\begin{array}{l}\text { 10) Local people } \\
\text { employment }\end{array}$ & $\begin{array}{l}\text { Constructio } \\
\mathrm{n} \text { of Roads }\end{array}$ & $\begin{array}{l}30 \% \text { of total } \\
\text { employment }\end{array}$ & $\begin{array}{l}\text { More than } 40 \% \\
\text { local people are } \\
\text { employed }\end{array}$ & & 100 \\
\hline $\begin{array}{l}\text { 11) Health and } \\
\text { sanitation/PPEs }\end{array}$ & $\begin{array}{l}\text { Constructio } \\
\mathrm{n} \text { of Roads }\end{array}$ & $\begin{array}{l}\text { EIA } \\
\text { recommended to } \\
\text { provide medical } \\
\text { facility and PPEs } \\
\text { for all workers }\end{array}$ & $\begin{array}{l}\text { Some facilities } \\
\text { are existing }\end{array}$ & $\begin{array}{l}\text { Simple medical facility, } \\
\text { PPEs are provide to } \\
60 \% \text { workers }\end{array}$ & 70 \\
\hline
\end{tabular}

the direct impacts and ii) Social Uplift program (SUP) to be spent to improve the indirect impacts. Construction of access roads at present is an ongoing activity. The compensations of intake of land and other properties have been paid and the mitigation measures of direct impacts are being carried out. Construction of road networks in remote areas of Melamchi valley itself is important benefit to the local people. The SUP is designed to minimize downstream effect of water diversion at Melamchi Valley. Some SUP activities are being carried out at this stage also but it does not seem to be right time. Occasionally the local people have threatened to stop the project for the following reason:

EIA has classified 17 VDCs to be directly affected and fall within the periphery of $500 \mathrm{~m}$ from the project. The area located beyond $500 \mathrm{~m}$ is considered as indirectly affected by the project. Only some part of 7 VDCs located within the road corridor are directly affected. However, the demands and grievances are coming from all 17 VDCs of the two districts. Meeting all demands of the local people, through the limited resources 
of the project is not possible. Local people are not properly informed about the limitation of the project. No systematic programs on the involvement of the local stakeholders have been found to be lunched. Problems are being solved and grievances are also being addressed only on peace-meal basis; however the local people continue to demand and tend to forget the benefits from the road networks in the area, and The project has made substantial contribution to the local communities. Adequate compensation has been paid for all losses, medical institutions and facilities have been strengthened, education facilities and scholarships have been established, local employment has been given top priority (in average 60 percent workers). However, these aspects of project's contribution to the local area have not yet been properly publicized and documented. By knowing the contribution of the project to the local area, the stakeholders of the project may develop positive attitude towards the project.

\section{CONCLUSION}

The EIA of Melamchi Water Supply Project is the basis for implementation of EMP. EIA strongly recommends implementation of mitigation measures for minimizing direct and indirect impacts arising from project. In total, 140 impacts (direct and indirect characters) have been identified and predicted. However, some predictions still lack justification. For example, the downstream release of water at the rate of $0.4 \mathrm{~m}^{3} / \mathrm{sec}$ is not adequately justified, as the amount of water required in downstream has not been properly investigated. Mitigation measures prescribed are too general; however, such prescriptions should provide guidance for developing specific actions.

Fixation of impact boarder of $500 \mathrm{~m}$ from the main project site and included 17 VDCs of two districts as directly project affected areas was a major blunder in the part of EIA. Based on $500 \mathrm{~m}$ criteria, only some part of 7 VDCs may fall within the project affected areas. This could have been demarcated in the project activity map. However, such demarcation has not been done and this has created problems. The local communities from all 17 VDCs are equally demanding the resources for their development. More VDCs, located away from the project site, are also interested to be named as project affected areas for getting resources from the project. Such problems have contributed in delaying the project implementation. Two important aspects of instant significance for actions are required to be implemented. They are: i) making criteria on the areas that the Melamchi Water Supply Project can support the local demands; and ii) proper dissemination of the contribution made by the project to the local area so far. Such information to the stakeholders will help to mollify the aggressiveness of the local people and facilitate adequate pace in the project execution.

\section{ACKNOWLEDGEMENT}

The authors are obliged to Mr. Suman Prasad Sharma, Executive Director, Mr. Khom B. Subedi, and Deputy Executive Director and Dr. Kiran Bhattarai, Environmental Specialist of Melamchi Water Supply Project for their support and encouragement.

\section{REFERENCES}

Bennie and Partners, (1988). Water Supply for Kathmandu- Lalitpure from outside the valley, PreFeasibility study, Final Report.

BPC, (1996). Hydro consult, Feasibility study of Melamchi Water Supply Project; Bankable Report, WSD, HMG.

Chaudhary, R.P., (1998). Biodiversity of Nepal: Status and Conservation, Series 17 Bangkok.

CEMAT/SchEMS. (2005). Inception Report on EMP implementation, submitted to MWSDB, HMG.

Central Bureau of Statistics. (1991-1998). National Planning Commission, HMG, Kathmandu Nepal.

CEMAT/SchEMS, (2005-2006). Monthly progress report on EMP implementation, series 1- 12, submitted to MWSDB, HMG.

CEMAT/SchEMS, (2006). An addendum to Inception Report on EMP implementation, submitted to MWSDB, HMG

Environmental Protection Regulation (EPR), (1997). Ministry of Population and Environment (MOPE), HMG

IUCN, (1999). The World Conservation Union in Association with METCON. EIA of Melamchi Water Supply Project, MWSDB, HMG. 
Khadka, R. B. and Khanal, A. B.

Melamchi Water Supply Project, (2003). Annual Report on Environmental and Social Activities for the year 2002 to 2003; Melamchi Water Supply Development Board, HMG.

METCON Consultants, (2001). Supplementary Environmental Impact Assessment of Melamchi Diversion Schemes (MDS) based on stand alone Water Supply only, MWSDB, and HMG.

MWSDB, HMG, (2005).Contract Agreement for Consulting Services on Environmental Management Program; JV of CEMAT and SchEMS.
Nippon Koei, N., (2000). EIA of Melamchi Water Supply Project, Volume I and Environmental Management Plan Volume II, MWSDB, HMG.

Norplan A. S., (1999). Melamchi Diversion Scheme: Main Technical Report, MWSDB, HMG.

Stanley and Associates. (1990). Environmental Impact Study: Future Water Supply from outside the valley for Katmandu-Lalitpur, Department of Water Supply, HMG 